\title{
Monitoring of the serum biomarkers during the therapy period of the patients with rheumatoid arthritis. Pilot Study
}

\author{
David Suchý', Ondřej Topolčan², Jindra Windrichová2, Radka Fuchsová2, Hana Brabcová', Soňa Loudová' \\ 'Department of Clinical Pharmacology, University Hospital in Pilsen, Charles University in Prague - \\ Medical Faculty in Pilsen, Czech Republic \\ ${ }^{2}$ Research Laboratory for Immunoanalysis, University Hospital in Pilsen, Charles University in Prague - \\ Medical Faculty in Pilsen, Czech Republic
}

\section{Monitorování sérových biomarkerů během léčby pacientů s revmatoidní atritidou. Pilotní studie}

Cíl: Proveřit možnost monitorace efektu anti TNFa terapie u pacientů léčených pro revmatoidní artritidu pomocí multiplexového stanovení sérových hladin vybraných biomarkerů odrážejících základní patofyziologické mechanizmy a aktivitu onemocnění. Metody: Byla hodnocena skupina 23 pacientů s aktivní revmatoidní artritidou, z toho 20 žen, 3 muži, průměrný věk 48,6 \pm 10,3 let, průměrná hmotnost 68,5 $\pm 13 \mathrm{~kg}$ před léčbou a po 14-16 týdnech léčby s inhibitorem TNFa adalimumabem $40 \mathrm{mg}$ subkutánně podávaným jednou za dva týdny ( $\mathrm{N}=21)$ nebo etanerceptem 25 mg podávaným podkožně dvakrát týdně $(\mathrm{N}=2)$. Z 23 pacientů, 16 (70 \%) užívalo současně s glukokortikoidy (GC) a 19 subjektů ( $84 \%)$ methotrexát. Krev byla odebrána ze žíly pomocí odběrové zkumavky Vacuette (Greiner Bio One, Rakousko). Krevní vzorky byly odstřed’eny při $640 \mathrm{~g}$ po dobu 10 min. Sérum bylo rozděleno na alikvoty a zamraženo do provedení analýzy při teplotě $-75^{\circ} \mathrm{C}$. Sérové hladiny IL $1 \beta$, IL10, IL6, VEGF, MMP9 a adiponektinu byly stanoveny multiplexovou analýzou pomocí technologie XMAP komerčním kitem Human Cardiovascular 1, Lineo Research (USA) podle návodu výrobce k použití. Analýza byla provedena na př́stroji Luminex 100 a analýza dat pomocí Luminex 100 IS software verze 2.3. Tyto parametry byly korelovány s krevními hladinami CRP, PCT, TK (stanoveno radioenzymaticky), hmotností pacienta a DAS-28. Pro všechny parametry byl vypočten průměr, medián, směrodatná odchylka, minimální a maximální hodnoty z výsledků před a po terapii. Data byla analyzována Wilcoxonovým párovým testem a koeficientem pořadové korelace.

Výsledky: Potvrdili jsme statisticky signifikantní snižení hladiny CRP $(p=0,001)$, VEGF $(p=0,05)$ a adiponektinu $(p=0,05)$, aktivity onemocnění hodnocené pomocí DAS-28 $(p=0,001)$ a významné zvýšení hmotnosti po léčbě $(p=0,01)$. Pokles hodnot všech tří prozánětlivých interleukinů nebyl významný.

Závěry: Naše pilotní studie prokázala potencionální využitelnost i limity multiplexové analýzy cytokinů a některých dalších biomarkerů v monitorování léčby revmatoidní artritidy. Ke stanovení doporučení pro rutinní klinickou praxi je nezbytné zvolit vhodnější panel a rozšrírit skupinu pacientů.

Kličová slova: revmatoidní artritida, blokátory TNFa, biomarkery, multiplexová analýza.

Monitoring of the serum biomarkers during the therapy period of the patients with rheumatoid arthritis. Pilot Study

Aims: To evaluate the possibility of monitoring the effect of anti TNFa therapy in patients with active rheumatoid arthritis by multiplex assessment of serum levels of different biomarkers which reflects underlying pathogenic mechanisms and activity of this disease. Methods: A group of 23 patients with active rheumatoid arthritis, 20 female, 3 male, average age 48.6 years \pm 10.3 , average weight $68,5 \pm 13 \mathrm{~kg}$ was evaluated prior therapy and after 14-16 weeks of therapy with TNFa blocking agent adalimumab 40 mg subcutaneously every two weeks $(\mathrm{No}=21)$ and etanercept $25 \mathrm{mg}$ subcutaneously twice weekly $(\mathrm{No}=2)$. Of 23 patients, $16(70 \%)$ of subject were treated concomitantly with glucocorticoids (GC), and 19 subject ( $84 \%$ ) with methotrexate. The blood was collected by venipunc- 


\section{| ORIGINÁLNÍ PRÁCE}

MONITORING OF THESERUM BIOMARKERS DURING THE THERAPY PERIOD OF THE PATIENTS WITH RHEUMATOID ARTHRITIS. PILOT STUDY

ture using Vacuette collection tubes (Greiner Bio-One, Austria). The blood samples were centrifuged at $640 \mathrm{~g}$ for $10 \mathrm{~min}$, serum was aliquoted and stored until analysed in freezer at $-75^{\circ} \mathrm{C}$. Serum levels of six parameters: IL 1 $\beta$, IL10, IL6, VEGF, MMP9 and adiponectin were assessed by multiplex immunoanalysis using XMAP technology with commercially available multiplex kits Human Cardiovascular 1 panel and Human Cytokines-Chemokines panel, both from Linco Research (USA) according to manufacturer's instructions for use. The analysis was performed on Luminex 100 instrument and data analysis on Luminex 100 IS software version 2.3. These parameters were correlated with blood levels of CRP, PCT, TK (assessed by traditional immunoassays), patient weight and DAS-2828. For all parameters there was counted average, median, standard deviation, minimal and maximal values from results prior and after therapy. Furthermore, data were analysed by Wilcoxon pair test and Rank-order correlation.

Results: We confirmed significantly decreased CRP levels $(p=0,001), \operatorname{VEGF}(p=0,05)$ and adiponectin $(p=0,05)$, disease activity score DAS-28 ( $p=0,001)$ and significant increase of weight after therapy $(p=0,01)$. Decrease of all of three proinflammatory interleukins were not significant.

Conclusions: Our pilot study showed the usefulness and limitations of multiplex measurements of cytokines and some other biomarkers in monitoring of rheumatoid arthritis therapy. But to establish guidelines for the routine clinical practice it is necessary to select preferable panel and to enlarge a group of the patients.

Key words: rheumatoid arthtitis, TNFa blocking agents, biomarkers, multiplex assessment.

\section{Introduction}

Rheumatoid arthritis (RA) is a chronic, systemic, inflammatory disease that leads to inviable joint destruction. Increasing numbers of cytokines have been involved in RA pathology. Advances in understanding the pathogenesis of the disease have fostered the development of new therapeutics. The utility of cytokines as therapeutic targets in rheumatoid arthritis has been demonstrated by the therapeutic success of tumour necrosis factor alpha (TNFa), interleukin 6 (IL-6) and interleukin 1 (IL-1) blockade. Tumor necrosis factor (TNF) inhibitors are used as a treatment for moderate to severe RA patients who have inadequate responses to conventional disease-modifying antirheumatic drugs (DMARDs) including methotrexate. In RA patients. TNFa blockade is associated with reduction in articular inflammation and damage and in improvement and subsequent changes in some composite activity measures (e.g Disease Activity Index DAS-28). However, up to one-quarter of patients with RA fail to respond to one or more of these drugs (1). For these reasons, a concerted effort has been made over the last decade to identify biomarkers of response to these agents. Certain demographic and clinical factors seem to influence the therapeutic efficacy of TNF inhibitors, including age, sex, smoking status and the presence of rheumatoid factor and anti-cyclic citrullinated peptide antibodies, but these factors together contribute $<20 \%$ of the variability in response to these agents (2). Therefore, focus has shifted to discovery of molecular biomarkers as predictors of response and several studies have been conducted to discover valid and reliable predictive biomarkers for RA therapies, which may provide guidancein determining optimal treatment in the context of personalised medicine. In RA, typical biological biomarkers encompass genetic markers, autoantibodies, cytokine or growth factors, acute phase reactants, cell subset and others. Nevertheless, the performance of biomarkers may greatly depend on the age of onset, duration of symptoms, the current level of inflammation as well as on the type of tissue tested. There are a number of conditions that can influence cytokine production including patient related variability, circadian rhytm, exercise, and preanaltical related variability. Furthermore, the complexity and heterogenous natur of RA further complicates such issues and limits thein clinical utility.

A clinical biomarkers (clinical variables) entcompass joint counts, pain score, duration of morning stiffness, functional scores and widely used composite activity indices.

In this study, we investigated whether some of selected biomarkers may represent useful predictive tool for efficacy anti TNF in patients who were initiating therapy with TNFi. We measured CRP, IL 1ß, IL10, IL6, VEGF, MMP9, TK, PCT and adiponectin. These parameters were correlated with blood levels of CRP, PCT, TK (assessed by traditional immunoassays), and clinical biomarkers -patient weight and DAS-28.

\section{Methods}

Baseline characteristics of the study population see table no. 1. Average prednisolone dose was $8.13 \mathrm{mg} \pm 6.62$, methotrexate average
Tab. 1. Baseline characteristics of the study population

\begin{tabular}{|l|l|}
\hline \multicolumn{2}{|l|}{ Number of subjects: $\mathbf{2 3}$} \\
\hline Female & 20 \\
\hline Male & 3 \\
\hline Age (years) & $48.6 \pm 10.3$ \\
\hline Weight (kg) & $68.5 \pm 13$ \\
\hline GC use (\%) & 70 \\
\hline MTX use (\%) & 83 \\
\hline Adalimumab (\%) & 91 \\
\hline Etanercept (\%) & 9 \\
\hline
\end{tabular}

dose was $9.84 \mathrm{mg} \pm 4$. Patients were evaluated prior therapy and after 14-16 weeks of therapy with TNFa blocking agent adalimumab administered as 40 mg subcutaneous injection every two weeks ( $\mathrm{No}=21$ ) and etanercept $25 \mathrm{mg}$ applicated subcutaneously twice weekly (No = 2). Baseline mean disease activity expressed as Disease Activity Score (DAS-28 28-FW ) - was high $(6.1 \pm 0.73)$, indicating active disease.

The blood was collected by venipuncture using Vacuette collection tubes (Greiner Bio-One, Austria). The blood samples were centrifuged at $640 \mathrm{~g}$ for $10 \mathrm{~min}$, serum was aliquoted and stored until analysed in freezer at $-75^{\circ} \mathrm{C}$.

Serum levels of six parameters: IL 1 $\beta$, IL10, IL6, VEGF, MMP9 and adiponectin were assessed by multiplex immunoanalysis using xMAP technology. The assays were run using commercially available multiplex kits Human Cardiovascular 1 panel and Human Cytokines-Chemokines panel, both from Linco Research (USA) according to manufacturer's instructions for use. The analysis was performed on Luminex 100 (USA) instrument and data analysis on Luminex 100 
ORIGINÁLNÍ PRÁCE I

Tab. 2. Change inmeasured biomarkers after 14-16 weeks of therapy with TNF a blocking agents

\begin{tabular}{|c|c|c|c|c|c|c|c|c|c|c|c|c|}
\hline \multirow[t]{2}{*}{ Parameter } & \multicolumn{4}{|c|}{ IL $1 \beta(p g / m L)$} & \multicolumn{4}{|c|}{ IL 10 (pg/mL) } & \multicolumn{4}{|c|}{ IL 6 (pg/mL) } \\
\hline & Mean & Median & Min & Max & Mean & Median & Min & Max & Mean & Median & Min & Max \\
\hline Prior therapy & 24.53 & 3.78 & 3.20 & 280.27 & 364.32 & 3.20 & 3.20 & 5538.51 & 102.25 & 66.56 & 3.20 & 392.98 \\
\hline After 14-16 weeks & 16.44 & 3.20 & 3.20 & 208.5 & 61.15 & 5.12 & 3.20 & 339.36 & 73.69 & 47.08 & 2.67 & 221.52 \\
\hline \multirow[t]{2}{*}{ Parameter } & \multicolumn{4}{|c|}{ VEGF (pg/mL) } & \multicolumn{4}{|c|}{ MMP 9 (ng/mL) } & \multicolumn{4}{|c|}{ Adiponectin ( $\mathrm{ng} / \mathrm{mL})$} \\
\hline & Mean & Median & Min & Max & Mean & Median & Min & Max & Mean & Median & Min & Max \\
\hline Prior therapy & 272.56 & 178.66 & 3.20 & 995.79 & 428.92 & 364.84 & 153.21 & 1158.42 & 18.29 & 17.81 & 8.05 & 25.00 \\
\hline After $14-16$ weeks & 205.32 & 153.94 & 3.20 & 820.66 & 391.66 & 326.88 & 106.10 & 1324.32 & 17.31 & 14.91 & 7.03 & 25.00 \\
\hline
\end{tabular}

Tab. 3. ???

\begin{tabular}{|c|c|c|c|c|c|c|c|c|c|c|c|c|}
\hline \multirow[t]{2}{*}{ Parameter } & \multicolumn{4}{|c|}{ CRP (mg/L) } & \multicolumn{4}{|c|}{ TK (IU/L) } & \multicolumn{4}{|c|}{ PCT $(\mu \mathrm{g} / \mathrm{L})$} \\
\hline & Mean & Median & Min & Max & Mean & Median & Min & Max & Mean & Median & Min & Max \\
\hline Prior therapy & 39.08 & 33.0 & 1.0 & 9.06 & 7.45 & 3.1 & 35.5 & 113.0 & 0.04 & 0.04 & 0.01 & 0.10 \\
\hline After 14-16 weeks & 22.22 & 7.0 & 1.0 & 9.36 & 7.3 & 2.7 & 26.4 & 138.0 & 0.04 & 0.03 & 0.01 & 0.29 \\
\hline \multirow[t]{2}{*}{ Parameter } & \multicolumn{6}{|c|}{ DAS-28 } & \multicolumn{6}{|c|}{ Weight (kg) } \\
\hline & \multicolumn{2}{|c|}{ Mean } & Median & \multicolumn{2}{|c|}{ Min } & Max & \multicolumn{2}{|c|}{ Mean } & Median & \multicolumn{2}{|l|}{ Min } & Max \\
\hline Prior therapy & \multicolumn{2}{|c|}{6.14} & 6.09 & \multicolumn{2}{|c|}{4.60} & 7.45 & \multicolumn{2}{|c|}{68.92} & 65.50 & \multicolumn{2}{|l|}{52.00} & 95.00 \\
\hline After $14-16$ weeks & \multicolumn{2}{|c|}{3.90} & 3.94 & \multicolumn{2}{|l|}{2.68} & 6.19 & \multicolumn{2}{|c|}{68.61} & 63.00 & \multicolumn{2}{|l|}{52.00} & 99.00 \\
\hline
\end{tabular}

IS software version 2.3. These parameters were correlated with blood levels of CRP, PCT, TK (assessed by traditional immunoassays), patient weight and DAS-28.

Statistical interpretation: There was counted average, median, standard deviation, minimal and maximal values prior and after therapy for all parameters. Furthermore, data were analysed by Wilcoxon pair test and Rank-order correlation.

\section{Results}

For results see Table 2 and 3. Parameters with significant changes are written in bold letters.

Note: DAS-28 above 5.1 means high disease activity whereas a DAS-28below 3.2 indicates low disease activity. Remission is achieved by a DAS-28 lower than 2.6 (comparable to the ARA remission criteria). Significant decrease in disease activity is achieved, when decrease in DAS-28 score $\geq 1.2$

\section{Discussion}

We found expected significant decrease of CRP ( $p=0.001)$, disease activity DAS-28 $(p=0.001)$ and increase of weight after thera$p y(p=0.01)$. From the other markers significant decrease after therapy was confirmed for VEGF $(p=0.05)$ and adiponectin $(p=0.05)$ only. This findings are in accordance with previously described results. Lack of correlation was observed between serum cytokine levels and disease activity (DAS-28). We registered non significant numerical decrease of all of the three interleukins. Changes of serum adiponectin levels show the link between RA, systemic inflammation and adiponectin concentrations and suggest its role in modulating of immune response in patients with RA.

Many clinical trials have reported the excellent clinical efficacy of tumour necrosis factor a (anti-TNFa) inhibitors in the treatment of rheumatoid arthritis (RA) (1). Several mechanism have been proposed to explain action of different TNF inhibitors. Neutralization of TNFa has a profound impact on the biology of inflammation and is reflected by the rapid reduction in the concentration of $C$ reactive protein (CRP), an acute phase protein. TNFa inhibition also showed ability to induce a rapid and marked reduction in circulating interleukin 6 (IL-6) levels, suggesting that its efficacy may result from the suppression of IL-6 as well as TNFa (1). In RA patients, IL-6 is detectable in elevated levels in the serum and synovial tissue together with its receptor IL-6R. IL-6 plays a crucial role in arthritis-related bone loss due to its involvement in osteoclast recruitment and activation. Levels of IL- 6 are tightly proportional to levels of $C$ reactive protein (CRP) and disease severity and blockade of IL-6 is generally accepted as therapeutic approach in treatment of RA patients $(2,3)$. An age-related increase in IL-6 concentration has been reported in serum obtained from elderly subjects. Some studies demonstrated that plasma levels of tumor necrosis factor are elevated in elderly populations (2). Postprandial cytokine levels are also affected by feeding; notably circulating IL-6 levels are increased while TNF-alpha levels are decreased (2).

The reduction of IL-1 synthesis in synovial tissue by an anti-TNF antibody in vitro was the pivotal observation that led investigators to suspect the involvement of a cytokine cascade in RA; however, it has been more difficult to verify these observations in vivo $(4,5)$. RA is associated with elevated levels of IL-1 in synovium. IL-1 is closely related to inflammation and articular damage in many arthritis models, IL-1 and TNF also play an important role in the degradation of articular cartilage by stimulating synovial fibroblasts and chondrocytes to secrete degradative enzymes, including matrix metalloproteinases (MMPs) $(2,6)$

Serologic analysis of extremely low levels of IL-1 with different assays has provided conflicting results, with significant reductions observed in one study and no consistent trend in another study $(5,7)$. IL-1, production exhibits gender related differences and distinct diurnal rhythms that peak in the early morning and are related to the rhythm of plasma cortisol and melatonin (2).

Interleukin 10 (IL-10) is a major immunoregulatory cytokine that is usually considered to mediate down regulation of the inflammatory response, as it inhibits the activation and effector functions of T cells, macrophages and monocytes. Regulatory T cells (Treg) are an important source of IL-10 production. It acts as a negative autocrine regulator of TNFa and other proinflammatory cytokines. Raised levels of IL10 


\section{| ORIGINÁLNÍ PRÁCE}

have been found in the serum and synovial fluid of patients with RA, possibly contributing to the diminished T-cell function and increased antibody and rheumatoid factor production (8-10). The influence of TNF alpha inhibition on serum IL-10 was described in patients with Crohn disease and ankylosing spondylitis, but data in RA patient are limited. High IL10 production has been found more frequently in patients with a higher rate of joint destruction and higher autoantibody titres. Regulatory T cells (Treg) are an important source of IL-10 production and this cell type might have been activated in vitro by etanercept. A restoration of function of Treg by infliximab in RA have been described. Enhancement of Treg cells in vivo and in vitro by TNFa-blockers may be probably another therapeutic mechanism of these substances $(9,11,12)$. Prolonged endurance type physical exercise can probably increase IL-10 levels in the circulation (2).

Several observations demonstrated reduction in serum VEGF concentrations after therapeutic intervention (13). Patients with early RA responding to disease-modifying antirheumatic drugs showed significant reductions in serum VEGF concentrations compared to non responders to the same treatment. Serum VEGF levels are reported to decrease under therapy with Infliximab in a dose-dependent way (14).

Adiponectin is an fat tissue protein that plays a role in maintaining the homeostasis of glucose and lipids and has an effect on insulin sensitivity. There is increasing evidence that adipocytokines may exert proinflammatory and destructive effects in RA. In addition to its metabolic properties, adiponectin has substantial immunomodulatory potential. RA is associated with increased serum adiponectin levels compared to healthy subjects and increased adiponectin is negatively linked to the local inflammatory process in patients with rheumatoid arthritis (17). It may be involved in the pathogenesis of rheumatoid arthritis (RA) by stimulating the expression of IL-6, IL-8, matrix metalloproteinase (MMP)-1 -13 in RA fibroblast-like synoviocytes. It was shown, that VEGF levels were positively correlated with adiponectin levels in RA joint fluid, but not in OA joint fluid (18). This adiponectin may play a significant role in the pathogenesis of RA by stimulating the production of VEGF and MMPs in fibroblast-like synoviocytes, leading to joint inflammation and destruction. Some recent reports suggest that tumour necrosis factor a (TNFa) blockade therapy can change circulating adiponectin levels, but data are sparse and inconsistent. Published results of two studys from 2010 do not support a significant effect of TNFa blockade therapy on circulating adiponectin levels in patients with autoimmune disease. No correlation was observed between changes in levels of adiponectin and C-reactive protein (19).

In our study, significant decrease of adiponectin serum levels in patients receiving anti TNF therapy was confirmed. This was accompanied with significant concomitant decrease in VEGF levels, confirming previous results listed above. Vascular endothelial growth factor (VEGF) has been demonstrated to have a central involvement in the angiogenic process in RA. The additional activity of VEGF as a vascular permeability factor may also increase oedema and hence joint swelling in RA. Serum VEGF showed sinificant correlation with C-reactive protein levels $(20,21)$. Interestingly serum VEGF concentrations have been found higher in patients with newly diagnosed RA than in those with long-standing disease (22).

MMP-9 activity may correlate with synovium proliferation with vascularization in rheumatoid arthritis. MMP-9 levels are substantially elevated in the sera and SF from patients with RA and may be a potentially useful laboratory marker of disease activity. MMP-9 in blood serum correlates significantly with disease activity and did not correlate with rheumatoid factor status $(14,15)$.

Early stages of RA showed high MMP-9 release and MMP-9 level is increased in stages II and III in RA, but this was not confirmed in more severe stage IV $(15,16)$.

The clinical significance of changes in serum procalcitonin (PCT) and thimidinkinase levels in patients with RA is not completelly understood and thein significance is not fully established. Significantly elevated PCT levels showed good specificity and sensitivity for systemic infection in patients with systemic autoimmune diseases, regardless of the use of corticosteroids or immunosuppressive agents $(23,24)$. Whether serum procalcitonin levels also reflect the activity of the underlying rheumatic disease is questionable. Information regarding plasma PCT levels in patients with active underlying systemic autoimmune diseases is limited (23). Howewer, as showed in our study, PCT monitoring may probably not contribute to better accuracy in measurement of disease activity and therapeutic response in patients with RA.

Thymidine kinase activity, an enzyme of salvage pathway in thymidine phosphate synthesis, is increased during high cell overturn caused by inflammation or tumour growth which requires higher DNA synthesis rate and it interferes in methotrexate mechanism of action as well (25). Thimidin kinase levels may be decreased by some antirheumatic drugs, mainly methotrexate, which is often used as monotherapy or in combination with anti TNF agents (25). In our study no changes of serum activity levels were observed after treatment.

There are number of features and conditions that can influence cytokine production: patiens related variability, diurnal rhytmicity and sample handling factors may influence the measurement of cytokine levels and are also likely to change not only with treatment but also with stres, kachexia and others. Such factors contribute cconsidferably to the limited usefulness of cytokine production in context of treatment monitoring.

\section{Conclusion}

Biomarkers allowing effective treatment strategy for a particular patient may represent essential step to the individual personalised medicine. Our pilot study has proposed the usefulness and limitations of multiplex measurements of cytokines and other biomarkers leading to complex monitoring of rheumatoid arthritis therapy as a supplement to nowadays scoring system (DAS28). In order to establish guidelines for the routine clinical practice it is necessary to use a larger panel of the parameters, take into account variability and limitations of cytokine measurement and to enlarge a group of the patients.

\section{Author's conflict of interest disclosure:}

The authors stated, that there are no conflicts of interest regarding the publication of this article.

\section{Abbreviations}

DAS-28 - Disease activity score, IL= interleukin, $\mathrm{RA}=$ rheumatoid arthritis, $\mathrm{CRP}=\mathrm{C}$-reactive protein, $\mathrm{PCT}=$ procalcitonin, $\mathrm{TK}=$ Thymidine Kinase, $\mathrm{GC}=$ glucocorticoids, MTX = methotrexate. 
ORIGINÁLNÍ PRÁCE I

\section{REFERENCES}

1. Hyrich KL, Watson KD, Silman AJ, Symmons DP. Predictors of response to anti-TNF-a therapy among patients with rheumatoid arthritis: results from the British Society for Rheumatology Biologics Register. Rheumatology (Oxford) 2006; 45: 1558-1565.

2. Burska A, Boissinot M, Ponchel F. Cytokines as biomarkers in rheumatoid artritis. Mediators of Inflammation Volume 2014 (2014), Article ID 545493, http://dx.doi. org/10.1155/2014/545493

3. Nishimoto N. Interleukin-6 in rheumatoid arthritis. Curr Opin Rheumatol 2006; 18: 277-281

4. Brennan FM, Chantry D, Jackson A, Maini R, Feldmann M: Inhibitory effect of TNF alpha antibodies on synovial cell interleukin-1 production in rheumatoid arthritis. Lancet 1989; 2: 244-247.

5. Charles P, Elliott MJ, Davis D, Potter A, Kalden JR, Antoni C, Breedveld FC, Smolen JS, Eberl G, deWoody K, Feldmann M, Maini RN: Regulation of cytokines, cytokine inhibitors, and acute-phase proteins following anti-TNF-alpha therapy in rheumatoid arthritis. J Immunol 1999; 163: 1521-1528. 6. Hosaka K, Ryu J, Saitoh S, et al. The comined effect of anti TNF alpha antipody and IL-1 receptor antagonist in human rheumatoid arthritis synovial membrane. Cytokine 2005; 32: 263-269

7. Lorenz HM, Antoni C, Valerius T, Repp R, Grunke M, Schwerdtner N, Nusslein H, Woody J, Kalden JR, Manger B: In vivo blockade of TNF-alpha by intravenous infusion of a chimeric mono-clonal TNF-alpha antibody in patients with rheumatoid arthritis. Short term cellular and molecular effects. J Immunol 1996; 156: 1646-1653.

8. Wanidworanun C, Strober W. Predominant role of tumor necrosis factoralpha in human monocyte IL-10 synthesis. J Immunol 1993; 151: 6853-6861.
9. Moore KW, de Waal MR, Coffman RL, O'Garra A. Interleukin-10 and the interleukin-10 receptor. Annu Rev Immunol 2001; 19: 683-765.

10. Chernoff AE, Granowitz EV, Shapiro L, Vannier E, Lonnemann $G$, Angel JB, et al. A randomized, controlled trial of IL-10 in humans. Inhibition of inflammatory cytokine production and immune responses. J Immunol 1995; 154: 5492-5499.

11. Lard LR, van Gaalen FA, Schonkeren JJ, Pieterman EJ, Stoeken G, Vos K, et al. Association of the -2849 interleukin-10 promoter polymorphism with autoantibody production and joint destruction in rheumatoid arthritis. Arthritis Rheum 2003; 48: 1841-1848.

12. Maynard CL, Weaver CT. Diversity in the contribution of interleukin-10 to T-cell-mediated immune regulativ. Immunol Rev 2008; 226: 219-233.

13. Paleolog EM, Young S, StarkAC, McCloskey RV, Feldmann M, Maini R Modulation of angiogenic vascular endothelial growth factor by tumor necrosis factor a and interleukin-1 in rheumatoid arthritis. Arthritis Rheum 1998; 41(7): 1258-1265.

14. Strunk J, Bundke E, Lange U. Anti-TNF-alpha antibody Infliximab and glucocorticoids reduce serum vascular endothelial growth factor levels in patients with rheumatoid arthritis: a pilot study. Rheumatology International 2006; 26: 252-256. 15. Takemura T, Kanbe K, Takeuchi K, et al. Serum matrix metalloproteinase activity relating to cartilage destruction in rheumatoid arthritis. APLAR Journal of Rheumatology $2005 ; 3: 213-219$

16. Gruber BL, Sorbi D, French DL, Marchese MJ, Nuovo GJ Kew RR, Arbeit LA. Markedly elevated serum MMP-9 (gelatinase B) levels in rheumatoid arthritis: a potentially useful laboratory marker. Clin Immunol Immunopathol 1996; 78(2): 161-171.

17. Senolt L, Pavelka K, Houza D, Haluzík M. Increased adi- ponectin is negatively linked to the local inflammatory process in patients with rheumatoid arthritis. Cytokine 2006; 35: $247-252$.

18. Goldstein BJ, Scalia R. Adiponectin: a novel adipokine linking adipocytes and vascular function. J Clin Endocrinol Metab 2004; 89: 2563-2568.

19. Peters MJL, et al. Lack of effect of TNFa blockade therapy on circulating adiponectin levels in patients with autoimmune disease: results from two independent prospective studies. Ann Rheum Dis 2010; 69: 1687-1690.

20. Marrelli A, Cipriani P, Liakouli V, et al. Angiogenesis in rheumatoid arthritis: A disease specific process or a common response to chronic inflammation? Autoimmunity Reviews 2001; 10: 595-598.

21. Afuwape AO, Kiriakidis S, Paleolog EM. The role of the angiogenic molecule VEGFin the pathogenesis of rheumatoid arthritis. Histol Histopathol 2002; 17: 961-972.

22. Latour F, Zabraniecki L, Dromer C, Brouchet A, Durroux R Fournie B. Does vascular endothelial growth factor in the rheumatoid synovium predict joint destruction? A clinical radiological and pathological study in 12 patients monitored for 10 years. Joint Bone Spine 2001; 68(6): 493-498.

23. Buhaescu I, Yood RA, Izzedine H. Serum procalcitonin in systemic autoimmune diseases--where are we now? Semin Arthritis Rheum. 2010; 40(2): 176-183.

24. Dejmková H, Šléglová O, Bečvář R, Pavelka K, Uhrová J. Omezený význam prokalcitoninu v odlišení septického stavu od vzplanutí autoimunitního onemocnění. Čes Revmatol 200; $17: 79-82$.

25. Tian HN, Cronstein BN. Understanding the Mechanisms of Action of Methotrexate: Implications for the Treatment of Rheumatoid Arthritis. Bulletin of the NYU Hospital for Joint Diseases. 2007; 65(3): s. 168-173. ISSN 1936-9719. 